
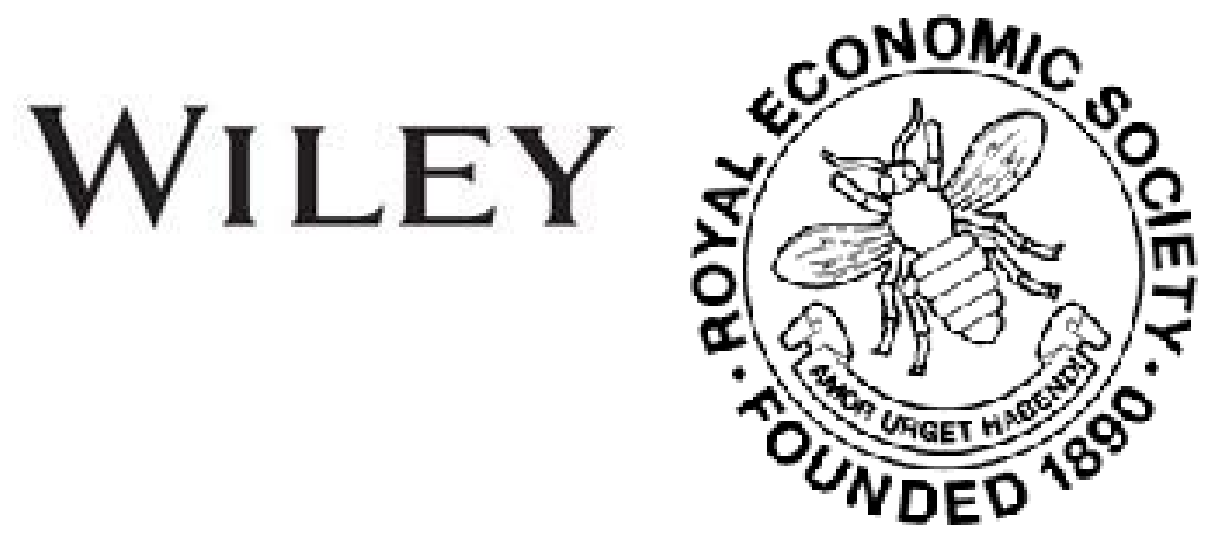

\title{
American Agricultural Commission
}

Author(s): Horace Plunkett

Source: The Economic Journal, Vol. 23, No. 90 (Jun., 1913), pp. 291-293

Published by: Wiley on behalf of the Royal Economic Society

Stable URL: http://www.jstor.org/stable/2222160

Accessed: 24-06-2016 21:09 UTC

Your use of the JSTOR archive indicates your acceptance of the Terms \& Conditions of Use, available at

http://about.jstor.org/terms

JSTOR is a not-for-profit service that helps scholars, researchers, and students discover, use, and build upon a wide range of content in a trusted digital archive. We use information technology and tools to increase productivity and facilitate new forms of scholarship. For more information about JSTOR, please contact support@jstor.org.

Wiley, Royal Economic Society are collaborating with JSTOR to digitize, preserve and extend access to The Economic Journal 


\section{American Agricultural Commission.}

Ir has been announced in the Press that an inquiry is about to be made on the Continent, and in the United Kingdom, into the organisation of agriculture by a large American Commission, including among its members delegates from most of the States of the Union and from one or more of the Provinces in the Dominion. They will arrive about July 8th in London, and sail from Queenstown on the 18th. The origin, scope, and purpose of the inquiry are set out in a Senate paper (Document No. 1071) ordered to be printed on February 11, 1913. But even those who have seen this Document, if they are not familiar with the sequence of events which led up to the appointment of the Commission may, I think, be assisted in understanding the real meaning of the inquiry by the supplementary information which I now offer to readers of THE ECONOMIC JOURNAL.

For the inception of the project it is not necessary to look far back. Towards the end of Mr. Roosevelt's administration a wave of new thought upon the social condition and economic needs of the farming population swept over the United States. Its growth was stimulated by the Conservation movement, the aim of which was to call public attention to the reckless waste of the natural resources of the country by exploiting capitalists, and to promote legislation to restrain it. In the course of the discussion it was frequently pointed out that by far the greatest national waste was to be found in the depletion of the fertility of the soil. Already the effect of bad husbandry was seen in the declining exports of agricultural produce. In the next few years, unless some radical change takes place, the United States will have to import some of its staple foods. The rising cost of living-the most vital question of the day in that country-is attributed by many to a faulty agricultural economy, the chief defect of which is the total lack of business organisation amongst those engaged in producing the nation's food. This disadvantage, under which these workers labour, is accentuated by the high degree of perfection attained in the organisation of other American industries, since in their mutual transactions organised interests prey upon the unorganised. Upon an unsound economic foundation no prosperous social life can be built up.

Whatever may be thought of such generalisations, it cannot be denied that, despite its unique physical opportunities, American agriculture, both as a social and as an economic force, is unnaturally and unnecessarily depressed. The thinkers of the towns are 
becoming more and more alive to their ultimate dependence upon the welfare of the farmers, and for the first time since the industrial revolution public opinion is beginning to give to agriculture its proper place in the national economy. This is, I think, a substantially accurate description of the state of facts which was held to need the serious attention of thoughtful men in the United States.

The first serious attempt to initiate a scheme of rural betterment was the appointment in 1908 of the Country Life Commission. This body held sittings, to which all and sundry were invited to come and give evidence as to local agricultural conditions, in almost every State in the Union. They published a report which did not immediately lead to action, but set people thinking. The daily Press and the popular magazines took up the "back-to-the-land" cry. The Federal Department of Agriculture, the universities and agricultural colleges, the churches and many other agencies of social progress, agitated questions of rural economy with increasing activity.

In April of last year an important and representative convention was held at Nashville, Tennessee, under the auspices of the Southern Commercial Congress-an Association of public men drawn from sixteen of the Southern States. Persuaded, I think it may be said, by the eloquent advocacy of Mr. David Lubin, the United States delegate to the International Institute of Agriculture in Rome, those present came to the conclusion that a reform in agricultural credit would practically solve all the serious difficulties which beset the farmer. The resolutions adopted at this convention called for the appointment of the Commission, for which the United States Senate subsequently bespoke diplomatic courtesies abroad.

The movement grew in popular favour. Each of the three parties in the presidential campaign included agricultural credit as a prominent part of their constructive policies. On December 7th, President Taft convened a meeting of Governors at the White House to discuss the project, at which it was decided to commend it to all the States. The appointment of delegates thereupon commenced, and the Southern Commercial Congress set about making the arrangements for the European tour.

Meanwhile economic thought, aroused by a state of facts above indicated, progressed rapidly, and a mere inquiry into agricultural credit no longer satisfied those who had adopted the new conception of the proper place for the country's basic industry. Moreover, the popularity of the project was being threatened by 
doubts, expressed in many quarters, as to whether agricultural credit-a highly technical subject on which there is abundant and excellent literature - was one which could be hopefully investigated by such a body as was proposed in a summer tour. It was therefore decided by the Southern Commercial Congress to instruct the Commission, instead of treating agricultural credit as the dominant, if not the only, factor in the development of rural life, to inquire into and report upon the entire organisation of the farmers' business in the countries to be visited. This change of procedure was approved by Mr. Taft, the then President, and was strongly endorsed by President Wilson and exPresident Roosevelt.

Readers of The Economic Journal will be chiefly interested in the concluding ten days of the European tour, which will be spent in the United Kingdom. Had the inquiry been, as originally projected, restricted to agricultural credit, little would have been learned in these islands. Indeed, there is only one issue within the scope of their inquiry, broadened, as has been explained above, upon which the Commission is likely to obtain valuable assistance. On this issue a few words may be usefully added.

By the time they arrive in England, the Commission will have learned the essential difference between the agricultural economy of the Continent, on the one hand, and that of the United States and other English-speaking countries on the other. It lies in the organisation of the farmers' business. In the former countries farmers have learned that methods of combination can be applied to agriculture as to all other important industries, provided the co-operative is substituted for the Joint Stock system of organisation. That lesson has been gradually learned by some of the farmers of the United Kingdom, first in Ireland, then in England, and later still in Scotland; it will also have to be learned in the United States. It is highly probable that the chief subject of inquiry over here will be the methods by which the English, Scottish, and Irish organisation societies are endeavouring to develop agricultural co-operation among the farmers of these islands.

Horace Plunkett

No. 90.- - VOL. XXIII. 